\title{
ENCONTROS ARTÍSTICOS E AYAHUASQUEIROS: REFLEXÕES SOBRE A COLABORAÇÃO ENTRE ERNESTO NETO E OS HUNI KUIN
}

Ilana Goldstein

Beatriz Caiuby Labate

\section{Introdução}

Em 2014 e 2015, o artista brasileiro Ernesto Neto criou instalações inspiradas em sua experiência entre os Huni Kuin, também conhecidos como Kaxinawa. ${ }^{1}$ Este texto é uma tentativa de refletir sobre questões suscitadas por essa aproximação entre um artista contemporâneo não indígena, fascinado pelos conhecimentos e artes da floresta, e alguns Huni Kuin dispostos a adentrar o universo das metrópoles e dos museus.

Tirando partido dos ângulos de visão de duas antropólogas com trajetórias distintas, ${ }^{2}$ e considerando que não encontramos nenhuma outra publicação acadêmica sobre a parceria entre Neto e os Huni Kuin, buscamos uma abordagem caleidoscópica que ajude a pensar sobre esta complexa interseção entre arte, espiritualidade, internacionalização e ressignificação de práticas e objetos tradicionais em novos contextos. Nosso principal objetivo foi construir uma problemática, articulando campos de conhecimento e autores de forma inovadora. Não pretendemos esgotar nem a etnografia, nem os tópicos mencionados, mas, antes, fazer com que se iluminem reciprocamente e ajudem a entender os intercâmbios culturais e as invenções indentitárias em curso.

Começamos introduzindo brevemente os Huni Kuin. Em seguida, traçamos um panorama da expansão do uso da ayahuasca nas cidades brasileiras e analisamos a progressiva presença indígena em museus de arte. Após esse pano de fundo contextual, apresentamos exposições em que Ernesto Neto e alguns Huni Kuin colaboraram de diversas maneiras. Uma exposição no Brasil e outra na Áustria merecem maior atenção, porque uma autora esteve diversas vezes na mostra de São Paulo, enquanto outra passou uma semana em contato com organizadores e artistas em Viena. O texto levanta, então, problematizações como o status legal da ayahuasca, a questão da propriedade intelectual coletiva, as negociações em torno da alteridade, apropriação cultural e ressignificação de objetos e práticas. 


\section{Os Huni-Kuin, a jiboia e os desenhos}

Os Huni Kuin, falantes de uma língua pano, vivem entre o Peru e o Brasil, próximos à fronteira entre os dois países. Sua população total gira em torno de 11.500 pessoas (Lima et al. 2014:221). Embora o povo Huni Kuin seja dividido em metades rituais e matrimoniais, é a divisão de gênero, marcada desde a infância, que organiza suas atividades cotidianas. Entre elas, está a produção da ayahuasca, tarefa masculina, e a pintura de jenipapo, feita pelas mulheres, principalmente em ocasiões festivas.

Haveria muitas práticas e aspectos do pensamento huni kuin que mereceriam ser destacados. Contudo, dados os nossos propósitos, optamos por comentar, ainda que rapidamente, os grafismos chamados de kene, presentes na pintura corporal, nas roupas e nos adereços que cobrem os Huni Kuin. De acordo com Els Lagrou (2008), humanos, animais, plantas e artefatos são classificados como possuidores ou não possuidores de desenhos. Os kene assinalam a "continuidade com o mundo de seres não humanos", permitem a "ligação com o mundo dos seres invisíveis" (Lagrou 2009:88) e estão intimamente associados à ingestão da ayahuasca e à jiboia. O cipó altera a visão das pessoas, que passam a ver seus corpos, o mundo que os envolve, os utensílios e o yuxibu $u^{3}$ da bebida cobertos por desenhos e pinturas (Lagrou 2013).

Similarmente ao que narram outros povos ameríndios - como os Wayana (Velthem 1998 e 2003) e os Wauja (Barcelos Neto 2001 e 2004) - os Huni Kuin do Acre relatam ter aprendido seus grafismos com um ser sobrenatural: foi o yuxibu da jiboia quem ensinou as mulheres a desenhar e revelou aos homens como preparar a ayahuasca (Lagrou 2007).

Tradicionalmente, o consumo da ayahuasca é frequente entre os homens huni kuin, em rituais que podem durar uma noite inteira. Os cantores detêm um poder especial, conduzem a experiência e, dependendo do caso, são capazes de ampliar o efeito da bebida. Eis o depoimento que o jovem Txana Bane deu a um pesquisador:

Nosso povo chama essa bebida de Nixi Pae, que, em nossa língua, quer dizer cipó forte. Essa planta é usada para curar vários tipos de doenças, tanto físicas como espirituais. [...] A ayahuasca possibilita conhecer um mundo diferente, dentro e fora da gente, que mostra o valor da vida humana e da natureza, dando sentido à caminhada da vida. O ritual acontece constantemente nas aldeias huni kuin, reunindo grupos em volta da fogueira, com todos cantando os cantos sagrados, chamando as forças da floresta [...] (Costa 2009:37). 
Barbara Keifenheim (2004), que trabalha com os Huni Kuin do Peru, assinala que experiências visuais liminares, vivenciadas em sonhos, estados febris e principalmente sob o efeito de psicoativos, fazem com que as pessoas participem sensorialmente de um cosmos em permanente metamorfose. A autora enfatiza a ligação entre o consumo de ayahuasca e a visualização/ produção de imagens entre os Huni Kuin e sugere que cada subespécie de cipó propicie visões com predominância de determinados motivos e cores (Keifeinheim 2004:98-99).

Ainda segundo a autora, as visões durante os rituais huni kuin com ayahuasca apresentam certa homogeneidade. Keifenheim (2004) cotejou diferentes etnografias e relatos orais e percebeu que, numa primeira fase, muitas pessoas veem desenhos geométricos, ao passo que, numa segunda fase, aparecem desenhos figurativos. Serpentes que envolvem os corpos ou entram por eles são abundantes. As imagens são acompanhadas por alterações acústicas e ganham força ao serem complementadas por sons. Os cantos são compostos por versos de sete sílabas entremeados por refrãos com sílabas onomatopaicas, como explica a pesquisadora alemã. O efeito do canto deriva menos dos textos do que do ritmo, do volume e do tom.

Tal caráter sinestésico da experiência com a ayahuasca entre os Huni Kuin é reiterado por Els Lagrou:

Os cantos são muito importantes pra produzir as visões, para guiar as pessoas que participam desse ritual e ensiná-los a ver aquilo que se procura ver e principalmente para não se perder. [...] O cipó é considerado a substância do corpo da jiboia, vem do cipó mas é a transformação da jiboia. Dizem que é o sangue ou a urina da jiboia. Quando você ingere o líquido vital desse ser, você se transforma em um deles. Você se torna Outro temporariamente, e esse Outro, se ele quiser se revelar, vai pintar o mundo pra você com seus desenhos e suas cores (Lagrou 2015: s.p.).

Os elementos mencionados acima - rituais com ayahuasca, grafismos geométricos, cantos, a onipresença da jiboia, a relação com a alteridade / a possibilidade de tornar-se Outro - constituem os ingredientes principais das criações artísticas de Ernesto Neto posteriores a seu encontro com os Huni Kuin, e se fazem notar igualmente em suas aparições públicas recentes. Em palestra no Instituto Tomie Otahke, em agosto de 2014, por exemplo, começou cantando, vestia um colete repleto de kene e grande parte de sua fala versou sobre o quanto aprendeu com os espíritos da floresta.

Convém observar que, nos últimos anos, os conhecimentos tradicionais huni kuin têm sido difundidos também a partir de outros projetos. ${ }^{4}$ Dois exemplos são emblemáticos. Um deles é Una Isi Kayawa - Livro da Cura 
(Muru \& Quinet 2014), que registra 109 espécies vegetais com suas respectivas aplicações medicinais. Foi idealizado pelo xamã e grande conhecedor de plantas Agostinho Ïka Muru, que morreu antes da finalização do livro; durante três décadas, ele fez anotações e desenhos em seus cadernos, além de ter formado pesquisadores indígenas. O livro é bilíngue e foi transcrito a partir de explicações orais. Alexandre Quinet, do Jardim Botânico do Rio de Janeiro, fez a ponte entre os conhecimentos indígenas e a ciência ocidental, ajudando na identificação das espécies. A obra foi impressa em papel com plástico PET, que resiste à umidade da floresta.

O lançamento do Livro da Cura ocorreu no Parque Lage, famosa escola carioca de artes visuais, na qual se construiu uma casa indígena, que abrigou 17 huni kuin por algumas semanas. Poucos meses depois, o Itaú Cultural, importante espaço cultural paulistano, premiou o Livro da Cura dentro do edital Rumos, viabilizando financeiramente sua continuidade.

A segunda empreitada editorial, Huni Kuin Hiwepaunibuki: a história dos Caxinauás por eles mesmos, saiu pelas Edições Sesc. Escrito em português, espanhol e kaxinawa, reúne desenhos, fotos, relatos sobre os ancestrais, as dispersões do grupo e as experiências com brancos. No prefácio, os autores explicam que a publicação é voltada a seus filhos e netos: "é para que os professores ensinem-lhes nossa história. E também para que não esqueçamos deles, nossos antepassados" (Camargo \& Villar 2013:29).

\section{A ayahuasca indígena nos centros urbanos}

Entre as décadas de 1980 e 1990, os grupos religiosos sincréticos do Santo Daime e da União do Vegetal (UDV), de origem amazônica, eram diretamente associados ao uso da ayahuasca (Labate 2004). Foi por meio destas duas igrejas que a beberagem chegou aos centros urbanos brasileiros, a partir do final dos anos 1970. Nos últimos anos do século XX, vertentes neoayahuasqueiras urbanas, que combinam elementos diversos como umbanda, budismo, nova era, psicologia esotérica e xamanismo, multiplicaram-se. Algumas estabeleceram extensões em várias cidades e até fora do país (Labate \& Coutinho 2014).

No século XXI, os próprios índios passaram a organizar rituais, palestras, encontros culturais e oficinas para não índios - membros da classe média urbana, artistas, estrangeiros - tanto em suas aldeias como em grandes cidades. Um dos casos emblemáticos é o dos Yawanawa. Aline de Oliveira (2012) relata que a Aldeia Nova Esperança, em Tarauacá, no Acre, promove o Festival Yawa desde 2001, em que não índios podem vivenciar cantos, danças e tomar ayahuasca. Segundo a autora, a "rede yawanawa" já chegou aos Estados Unidos e à Europa. 
Desde 2002, Fabiano e Leopardo Yawa Bane, filhos de Siã, importante liderança huni kuin, organizam rituais e fazem aplicações de kampô secreção retirada do sapo Phyllomedusa bicolor - no Rio de Janeiro e em São Paulo. ${ }^{5}$ Os irmãos são pioneiros da expansão do uso indígena da ayahuasca no Brasil, tendo influenciado a chegada de outras etnias aos centros urbanos.

Fabiano Huni Kuin, que atualmente mora em Berlim, costumava conduzir mensalmente no Rio de Janeiro "rituais do nixi pae" que, de acordo com o material de divulgação, se propunham a "limpar, ensinar e esclarecer" (Coutinho 2015:2). Os rituais aconteciam nos finais de semana, em áreas verdes. O pajé, como é chamado por seus seguidores, portava seus paramentos rituais - cocar, braceletes de miçangas e pintura facial - e cantava até o raiar do sol, induzindo visões da jiboia e evocando energias de cura. Os interessados costumavam ser pessoas com alto nível de instrução buscando reequilíbrio físico e mental. Os organizadores das cerimônias, conhecidos como "guardiões huni kuin", ocupavam-se da divulgação, de pagamentos, transporte e entrevistas prévias (Coutinho 2015:6).

Fabiano foi o primeiro a reivindicar publicamente a origem indígena da ayahuasca, afirmando a uma revista semanal que seu avô teria apresentado a bebida ao Mestre Irineu, fundador do Santo Daime. Em 2012, foi a vez de Benki Piyanko, um ashaninka de uma aldeia no Acre, dizer à Carta Capital que o seu avô foi quem ofereceu o chá ao Mestre Irineu (Labate \& Coutinho 2014). A disputa em torno da "paternidade" ganha novos contornos quando lembramos que a patrimonialização da ayahuasca está em curso no Brasil, e que o processo de registro envolve a identificação dos detentores de um conhecimento tradicional (Labate \& Goldstein 2008).

Em 2008, foi feito um pedido de registro ao Instituto do Patrimônio Histórico e Artístico Nacional (Iphan) por parte de três das maiores religiões ayahuasqueiras: União do Vegetal, Santo Daime e Barquinha. Antes disso, elas já haviam conquistado espaço no âmbito das políticas culturais de Rio Branco, com papel de destaque no Conselho Municipal de Cultura, que abriga uma câmara temática exclusiva para a ayahuasca (Goulart 2016) . Os grupos ayahuasqueiros entenderam ser estratégico estabelecer um novo canal de diálogo com o Estado brasileiro, não mais via políticas antidrogas, mas via Ministério da Cultura. Até esse momento, os índios estavam excluídos do debate.

Em 2010, representantes de povos falantes de línguas pano - em que é recorrente o consumo de ayahuasca - se dirigiram ao Ministério da Cultura para reclamar de terem sido excluídos do primeiro pedido de registro. O Iphan, então, pediu que fosse realizado um inventário cultural abrangendo outras vertentes, inclusive indígenas e ecléticas. Assim, no Acre, os 
anos de 2011 e 2012 assistiram a esforços e negociações das comunidades ayahuasqueiras e de instituições públicas locais com vistas à elaboração de um inventário cultural que fornecesse as bases para se chegar a um núcleo comum a ser registrado no Iphan (Labate \& Coutinho 2014).

Nos últimos anos, portanto, os índios passaram a ter alguma voz no debate público sobre a ayahuasca, além de maior presença no circuito esotérico e de terapias alternativas. O elemento indígena, antes silenciado, agora é acolhido tanto pelo Iphan quanto no discurso dos próprios grupos ayahuasqueiros. A origem indígena da ayahuasca tem sido cada vez mais associada a ideias como ancestralidade e autenticidade. O curioso é que foram os sujeitos do circuito Nova Era e urbano que trouxeram o elemento indígena para dentro do debate público (Labate \& Coutinho 2014).

Como veremos a seguir, no universo artístico ocorrem processos semelhantes de inserção lenta e gradual do elemento indígena, muitas vezes com o apoio de não índios, fascinados pela alteridade e em busca de uma autenticidade que teria sido perdida no mundo capitalista.

\section{Presença indígena em museus e galeria de arte}

De um modo geral, artes e artistas indígenas ainda são raros, tanto no circuito expositivo como no mercado de arte. Um dos fatores de sua exclusão é o pressuposto euro-americano da primazia da forma, em detrimento das dimensões rituais ou utilitárias de objetos e performances. Outro obstáculo à circulação de trabalhos indígenas no sistema das artes é o postulado moderno da inovação permanente, que vem acompanhado pelo desprezo à repetição de padrões. Segundo Nathalie Heinich (1998), hoje, para que um objeto ou uma performance sejam percebidos como obras, são necessárias três condições: 1. a ausência de outras funções explícitas que não a estética; 2. a assinatura de um artista ou de um grupo de artistas reconhecido pelas instâncias de legitimação; 3. a crença de que o trabalho é insubstituível, devido à sua originalidade e à sua unicidade. É claro que tais pressupostos são contingentes e questionáveis. Contudo, acabaram se universalizando e se transformando em categorias normativas, desqualificando as demais criações (Colombres 2005). A marginalização das artes indígenas e dos artistas autodidatas ilustra esse processo. Não foi à toa que receberam rótulos como arte "primitiva" e arte naif (ingênua).

Há que se considerar, também, que até pouco tempo objetos indígenas costumavam ser expostos exclusivamente em museus etnográficos ou de História Natural. A Antropologia nasceu atrelada a tais museus científicos, 
que abrigavam a "cultura material" dos povos por ela estudados. A maioria dos museus etnográficos floresceu no final do século XIX, sob influência do paradigma evolucionista, como atestam, por exemplo, o National Museum, na Holanda, de 1837, e o Peabody Museum, nos Estados Unidos, de 1866 (Schwarcz 2013). Por várias décadas, um dos principais objetivos das pesquisas de campo dos antropólogos foi ampliar as coleções dos museus. E as exposições desses objetos tinham teor informativo/educativo, deixando em último plano preocupações estéticas.

No início do século XX, porém, as vanguardas modernas aproximaram-se de algumas das peças guardadas em museus etnográficos com um novo olhar. Essa atitude, posteriormente chamada de primitivista, serviu, acima de tudo, para os artistas criticarem os cânones de sua própria sociedade. A mesma inclinação primitivista está por trás dos rostos angulosos de Picasso, que remetem a máscaras africanas (Perry 1998), das estadias de Gauguin no Haiti, das aquisições de peças da África e da Oceania por Matisse e Vlaminck, e da incorporação de objetos e temas xamânicos de povos da Groenlândia nas telas de Kandinsky (Weiss 1995).

Se, para os artistas modernos, objetos "primitivos" constituíam um reservatório de novas formas (Clifford 1998), isto não significa que tivessem interesse em compreender o sentido dos objetos em seus contextos de origem. Els Lagrou (2008) ressalta que os surrealistas não se interessavam pelas sociedades das quais os objetos eram oriundos. Carlo Severi (2012), por sua vez, afirma que as vanguardas artísticas cultivavam desconfiança em relação a qualquer abordagem antropológica - Picasso, por exemplo, dizia que só olhando para peças africanas já tinha todas as informações que desejava.

De todo modo, ao longo do século XX, objetos produzidos por indivíduos e coletivos indígenas permaneceram a maior parte do tempo com o status de artefatos, fora dos museus de arte. Exposições temporárias isoladas são exceções que confirmam a regra. Na década de 1980, duas mostras propuseram aproximações com criações indígenas: "Primitivism in 20th Century Art: Affinity of the Tribal and the Modern", organizada pelo MoMA, em 1984, obliterou a história e o significado das peças "primitivas" expostas, ao tratá-las unicamente do ponto de vista das afinidades formais com trabalhos de artistas modernos. Já "Magiciens de la Terre", que ficou em cartaz no Centre George Pompidou e no Parque La Villette, em 1989, inovou ao identificar os artistas, porém aproximou, sem mediação, trabalhos completamente diferentes, tendo um suposto aspecto "mágico" como denominador comum (Karp 1991). 
Em 2006, a inauguração do Musée du Quai Branly, em Paris, talvez tenha sinalizado o surgimento de um novo modelo: a "artificação" (Shapiro \& Heinich 2013) do que antes se considerava como artefatos etnográficos. Ao serem transferidas de museus científicos e históricos para o novo edifício projetado pelo festejado arquiteto Jean Nouvel, ao lado da Torre Eiffel, com iluminação dramática e poucos textos explicativos, máscaras africanas, cocares xinguanos, cerâmicas amazônicas e muitas outras peças se tornaram, como formulou Jacques Chirac no dia da abertura, "obras de arte das culturas do mundo" (Goldstein 2008; Price 2007; L'Estoile 2007).

Não poderíamos deixar de mencionar aqui dois países em que as artes e os artistas indígenas conquistaram espaço institucional surpreendente: Canadá e Austrália. Tanto no caso australiano como no canadense, o surgimento de uma nova produção artística indígena se deu a partir da intensificação do contato com não indígenas no último quarto do século XX; em ambos os países, há subsídios do governo, que vê a arte indígena como uma fonte de renda e de fortalecimento comunitário; museus e galerias comerciais dos dois países expõem e vendem trabalhos indígenas como arte (Berlo 1999; Goldstein 2012). Além disso, na Austrália e no Canadá os artistas indígenas tendem a se associar em cooperativas autogeridas (Goldstein 2012; Mitchell 1993).

A situação da Austrália é provavelmente única. Estima-se que existam, hoje, cerca de 7.000 artistas e 20 curadores indígenas no país, muitos dos quais participam regularmente de bienais e premiações artísticas (Goldstein 2013a e 2016). O último levantamento realizado sobre o volume de vendas da arte indígena da Austrália variava entre 200 e 300 milhões de dólares por ano (Altman 2005). E não se trata de uma atividade meramente comercial. O fazer pictórico reúne diversas gerações de uma mesma família e estimula a transmissão de conhecimentos tradicionais. Os mais velhos recontam mitos e entoam canções enquanto os traduzem em pinceladas, formas e cores. Ademais, em torno das cooperativas artísticas têm surgido articulações políticas importantes (Morphy 2008).

Em outros países, como Estados Unidos, artistas indígenas vêm despontando individualmente. Na Bienal de São Paulo de 2010 contamos com uma instalação do cherokee Jimmie Durham, que consistia em um pseudomuseu etnográfico. Em meio a estantes de madeira e objetos legendados, Durham inseriu artigos de jornal sobre massacres indígenas no Brasil. Embaixo de uma foto do Monumento às Bandeiras, de Brecheret, escreveu se tratar de uma "ode ao genocídio". Entretanto, artistas indígenas com a visibilidade de um Jimmy Durham não são numerosos - e, até pouco tempo, eram inexistentes no Brasil. Tampouco se encontram no Brasil políticas sistemáticas de fomento à produção artística dos povos indígenas, não obstante o enorme potencial de formas expressivas oriundo de nossa diversidade étnico-cultural. 
Um último aspecto importante, nesse breve panorama das interfaces entre o sistema das artes e os povos indígenas, é a "virada etnográfica" na arte contemporânea, observada na década de 1990, quando alguns artistas euro-americanos começaram a utilizar procedimentos etnográficos e a discutir políticas de representação em seus trabalhos. Claire Pentecost, por exemplo, realizou, em 1990, uma instalação inspirada em Ishi, último representante do povo Yahi, que foi encontrado na Califórnia por Alfred Kroeber, faminto e com os cabelos queimados. Ishi viveu alguns anos no Museu de Antropologia de São Francisco e morreu em 1916. A matéria-prima do trabalho de Claire foram respostas a questionários que ela enviou a nativos norte-americanos pedindo que relatassem o que sabiam e o que pensavam sobre o caso Ishi. Lothar Baumgarten, por sua vez, expôs na X Documenta de Kassel, em 2007, fotocópias de fotografias que tirou de um grupo Ianomami na Venezuela. O catálogo se referia ao trabalho como "antropologia poética". Evidentemente, não se trata da produção sistemática de conhecimento pautada por paradigmas científicos, mas da livre experimentação com o não familiar, da justaposição de perspectivas e da interação com grupos marginalizados.

No âmbito acadêmico, um dos motes de debate tem sido o "fim da história da arte", anunciado por Hans Belting. "A assim chamada história da arte é uma invenção de utilização restrita e para uma ideia restrita de arte" (Belting 2006:101). O autor argumenta que, no modernismo, uma barreira protegeu a arte euro-americana da "contaminação" pela arte étnica e popular. Hoje, ao contrário, a arte "global" interpela a arte pós-étnica, indígena, ex-"primitiva", ou como se queira chamá-la. Para refletir sobre esse cenário, sem ignorar as assimetrias de poder que vigoram no sistema internacional das artes, Belting sustenta que diálogos interdisciplinares são fundamentais.

\section{Formas expressivas indígenas, museus e mercado no Brasil}

Uma história completa das exposições de artes indígenas no Brasil ainda está por ser escrita, mas não seria muito extensa. Mencionamos a seguir três eventos emblemáticos. A 17ª Bienal de São Paulo, em 1983, foi inovadora ao preparar uma seção intitulada "Arte Plumária do Brasil", que mereceu um catálogo à parte. O belo conjunto já havia ficado em cartaz por um mês no Museu de Arte Moderna de São Paulo, em 1980, mas a inserção na Bienal Internacional lhe deu maior visibilidade e ensejou uma nova organização temática, ao invés da classificação anterior por grupos étnicos. Outra iniciativa pioneira foi "Artes Indígenas", na Oca do mesmo Parque do Ibirapuera, em 2000. Integrante de um evento mais amplo, chamado 
"Mostra do Redescobrimento", teve curadoria do antropólogo português José António Braga Fernandes Dias. Mais recentemente, tivemos "Mira!", compilação de artes indígenas da América Latina com ênfase nos Andes, idealizada por Maria Inês de Almeida, da UFMG, que circulou entre 2013 e 2015, em Brasília e em Belo Horizonte.

Existem alguns artistas indígenas com carreira individual no Brasil, porém, ainda sem muito valor de mercado, nem visibilidade, como o wapixana Amazoner Okaba. O macuxi Jaider Esbell e a pataxó Arissana Braz foram ambos indicados para o Prêmio PIPA de Arte Contemporânea em março de 2016, o que representa, talvez, o início de sua inserção institucional. Porém, são raríssimas as galerias brasileiras que comercializam trabalhos indígenas.

Observam-se parcerias comerciais entre não indígenas e indígenas nas áreas do design, da moda e da arquitetura em que, por exemplo, ceramistas kadiweu produziram azulejos que hoje decoram edifícios em Berlim, projetados pelo escritório Brasil Arquitetura; grafismos kayapó estampam roupas vendidas pela grife carioca FARM (Goldstein 2013b); e pinturas corporais ksêdjê cobriram Gisele Bündchen numa campanha da Grendene ${ }^{6}$ (Souza 2012).

Em um país com as dimensões e a etnodiversidade do Brasil, as iniciativas ainda nos parecem modestas e esparsas. ${ }^{7}$ Por isso mesmo, o fato de alguns huni kuin estarem participando de eventos em instituições de arte contemporânea consagradas chama a atenção. Ibã Sales é um deles. Nascido em 1964, na Terra Indígena do Rio Jordão, Acre, Ibã alfabetizou-se em cursos para professores indígenas e, nos anos 1990, passou a registrar os conhecimentos contidos nos cantos da ayahuasca juntamente com seu pai, com quem diz ter aprendido tudo. Em 2006, publicou seu primeiro livro, Nixi Pae. O Espírito da Floresta (Ibã 2006); em seguida, lançou Huni Meka. Os cantos do cipó, livro com dois CDs e um DVD (Ibã 2007). Ibã coordena também o Mahku - Grupo de Jovens Artistas Desenhistas Huni Kuin, que traduz músicas rituais para a linguagem visual. ${ }^{8}$

Em 2012, o coletivo Mahku esteve em Paris, participando da exposição da Fondation Cartier pour 1'Art Contemporain "Histoires de Voir - Show and Tell". Outra encomenda artística lhe chegou em 2014, quando o grupo foi convidado a realizar uma intervenção no Hospital Matarazzo, em São Paulo, onde 111 artistas brasileiros e estrangeiros expuseram trabalhos em corredores, pavilhões e jardins do complexo hospitalar desativado. O evento, gratuito e muito divulgado na mídia, formou filas. Para esta intervenção, Ibã teve ajuda do filho Bane e do genro Isaka. Eles pintaram uma grande jiboia nas paredes e no teto de um saguão de $150 \mathrm{~m}^{2}$. O convite partiu da belga 
Naziha Mestaoui, que assinou, no mesmo espaço, a instalação "Sounds of Light". Tratava-se de um mecanismo que transformava as vibrações de cantos huni kuin gravados em ondulações na água e variações nas luzes coloridas. Os artistas indígenas tiveram seus custos de viagem e hospedagem cobertos pelo evento, mas só a artista belga foi remunerada, pois ela era a convidada oficial. Soubemos pelos produtores da exposição que Naziha Mestaoui decidiu, por iniciativa própria, fazer uma doação de R\$ 10.000 ao Mahku.

No mesmo ano, o coletivo artístico huni kuin participou de "Histórias Mestiças", concebida pela antropóloga Lilia Schwarcz e pelo curador de arte Adriano Pedrosa, e que ficou em cartaz no Instituto Tomie Otahke. A exposição evitava a separação entre arte e documento, entre popular, moderno, "primitivo" e contemporâneo. Segundo os curadores, o objetivo era expor lado a lado artistas de diferentes períodos, regiões e etnias.

Numa parede do corredor central de "Histórias Mestiças", letras dos cantos do ritual huni meka se encontravam figuradas em desenhos multicoloridos assinados pelos membros do Mahku. Falavam de como os antepassados conseguiram encontrar o cipó (da ayahuasca) e como aprenderam suas músicas. Remetiam ao mito da jiboia primordial, reverenciada pelos Huni Kuin e por outros povos ameríndios. Os desenhos do Mahku ficavam em frente à instalação de Ernesto Neto, que também se referia às tradições huni kuin. Entretanto, a parceria de Ernesto Neto não se deu diretamente com os desenhistas do Mahku.

Figura 1. Isaka e Ibã Huni Kuin. Yube inu. "Histórias Mestiças", 2014

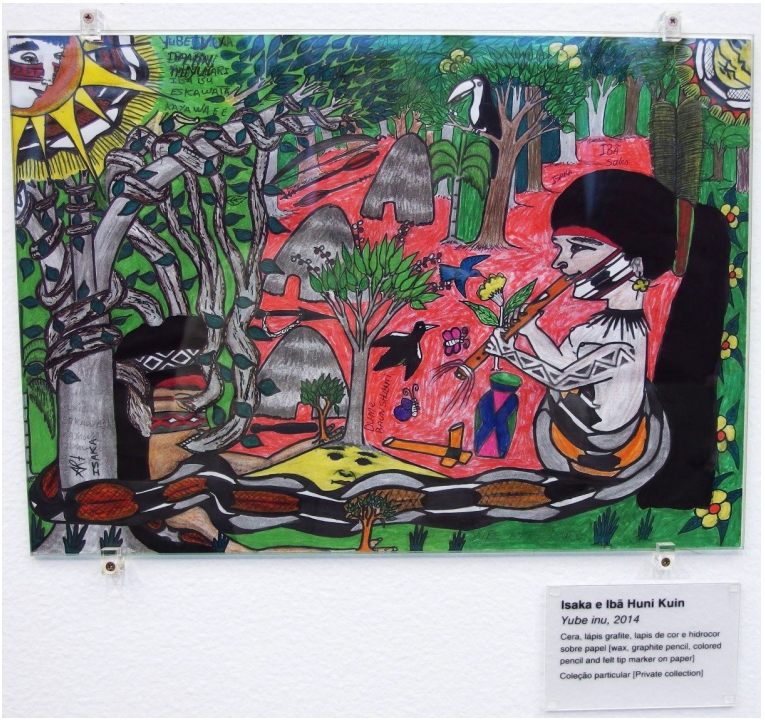

Foto: Christian Strube 
Figura 2. Isaka e Ibã Huni Kuin. Puke duã ainbu.

"Histórias Mestiças", 2014

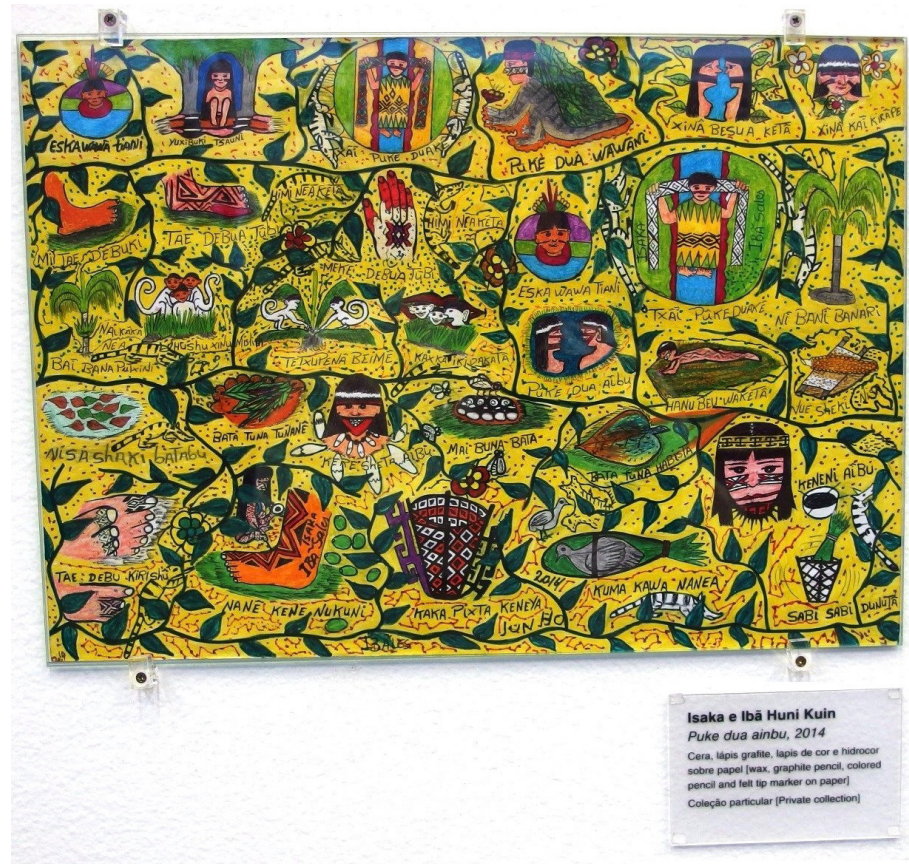

Foto: Christian Strube

Uma forma adicional de aproximação entre os universos ameríndios e o sistema das artes vem se fortalecendo: as curadorias e as obras feitas por não indígenas tematizando questões indígenas. Cláudia Andujar, que conviveu com os Ianomami nos anos 1970 e 1980, é autora de fotografias impactantes, com jogos de luz e sombra, que são fruto dessa experiência. Em novembro de 2015, foi inaugurado um pavilhão para suas fotos no Instituto Inhotim, em Minas Gerais, uma das maiores coleções de arte contemporânea da América Latina. Poucos meses antes, no Paço das Artes, em São Paulo, o curador Moacyr dos Anjos assinou a mostra "A queda do céu" - título que remete ao livro homônimo escrito pelo xamã ianomami Davi Kopenawa junto com o antropólogo Bruce Albert. De maneira direta ou indireta, os trabalhos se referiam à questão da terra ou aos conflitos oriundos do contato.

Ainda em 2015, Alfons Hug concebeu a instalação "O Papagaio de Humboldt", primeiramente exposta no Parque Ibirapuera e depois na Bienal de Veneza. Hug propôs que 15 artistas latino-americanos fizessem registros de pessoas falando línguas indígenas, difundidos em alto-falantes dispostos circularmente. Ao lado dos alto-falantes, havia textos traduzindo as locuções, 
que podiam ser denúncias, mitos, relatos históricos, receitas e assim por diante. Vale mencionar ainda uma instalação de videogame concebida por Guilherme Meneses, doutorando em Antropologia na USP, com participação de representantes de 32 aldeias do Baixo Rio Jordão, que esteve em cartaz no Itaú Cultural no mesmo ano. Os protagonistas do jogo interativo "Huni Kuin - os caminhos da jiboia" são irmãos gêmeos que nascem da jiboia e que, após superarem os obstáculos do percurso, viram um pajé e uma mestra de desenhos.

Haveria alguns outros exemplos similares e recentes, muitos deles compilados em Calabi (2016). Mas estes já ajudam a esboçar o cenário no qual a colaboração entre Ernesto Neto e os Huni Kuin se torna possível e ganha sentido. De todo modo, arriscamos apontar que, no momento atual, a agência indígena no debate sobre ayahuasca - inclusive em meios urbanos e acadêmicos - é maior do que no campo das artes, o que, aliás, torna o estudo do caso Ernesto Neto / Huni Kuin particularmente relevante.

\section{Encontros entre Ernesto Neto e os Huni Kuin}

Ernesto Neto é um artista carioca nascido em 1964, cuja bela obra tridimensional se situa entre a escultura e a instalação. Neto realizou mostras individuais no Museu de Arte Moderna de São Paulo, no Paço Imperial do Rio de Janeiro, no museu mexicano Carrillo Gil, no Contemporary Arts Museum de Houston, entre outras instituições; participou de coletivas no MoMA e na Bienal de Veneza, entre dezenas de locais. E foi o primeiro brasileiro premiado pelo Aspen Art Museum por sua contribuição à arte contemporânea. De acordo com uma reportagem da Época, os trabalhos de Neto podem alcançar U\$ 400.000 (Padilla 2010). Na feira ArtRio de 2014, uma interlocutora de nossa pesquisa contou que um trabalho pequeno de Neto foi vendido por $\mathrm{R} \$ 280.000$.

As matérias-primas básicas de Ernesto Neto costumam ser tecidos elásticos (que pendem do teto, como gotas); bolinhas de isopor (que preenchem partes deste tecido); e temperos (que conferem odor aos espaços). Com estes elementos, constrói ambientes envolventes que têm aspecto vivo, como amídalas ou vísceras. A Galeria Fortes Villaça, que representa o artista, descreve sua poética: “[...] O espectador é convidado a participar, tocando, cheirando ou adentrando o espaço da escultura. As formas orgânicas relacionam-se com a observação do corpo como representação da paisagem interna do organismo, numa analogia entre o corpo e a arquitetura". ${ }^{9}$ 
"The body that carries me" foi a mostra individual do artista no Museu Guggenheim de Bilbao, em 2014. Segundo nossa pesquisa de campo, na abertura, o jovem Txana Bane e seu pai, Siã Sales, fizeram uma pajelança. Ernesto Neto os conhecera ao acompanhar uma amiga no projeto Livro da Cura. Neto foi ao Acre algumas vezes, desde 2013, e depois participou de sessões de ayahuasca no Rio de Janeiro. Ficou tão impressionado que, na exposição de Bilbao, uma sala remetia às árvores da floresta amazônica e uma instalação tinha o formato de uma serpente suspensa. O curador Adriano Pedrosa esteve em Bilbao, e resolveu fazer o convite para uma instalação em "Histórias Mestiças". Nessa instalação, intitulada Em busca do Sagrado: nixi pae e a jiboia, Neto criou uma sala para sediar rituais com ayahuasca, que ocorreram duas vezes na madrugada, dentro do Instituto Tomie Otahke.

Leopardo Kaxinawa e outros indígenas colaboraram com Ernesto Neto nas cerimônias, cantando, soprando tabaco, tocando maracá e servindo ayahuasca para as pessoas que se inscreveram. Para participar do ritual no museu, era preciso, antes, passar por uma entrevista, em que era levantado o estado psíquico e físico do interessado. Assinava-se também um termo de responsabilidade. No audioguia da exposição, o curador afirmava: "É extraordinário o museu se abrir desta maneira para abrigar isso, que canibaliza o museu. [...] É uma cerimônia religiosa e terapêutica. Podem ocorrer insights e descobertas interiores. É a primeira vez que se faz isso no Brasil, no contexto de uma exposição".

O espaço penetrável, com cores leves, assentos no chão e cheiro de cravo, propunha uma experiência sensível e corpórea. Tinha a forma de uma jiboia, na qual se entrava pela boca. A barra do tecido, à volta da jiboia, era composta por tampinhas de garrafa coloridas que, com os esbarrões, soavam como um chocalho de sementes - como um que ficava pendurado no centro da tenda-jiboia. Tampinhas coloridas também compunham um maracá sobre a mesa de mármore curvilínea sobre a qual ficava uma garrafa de ayahuasca. A concepção plástica da instalação era de Ernesto Neto, remetendo à sua pesquisa anterior, bastante coesa e característica. Os indígenas contribuíram principalmente conduzindo os rituais dentro da instalação. 
Figura 3. Em busca do sagrado: nixi pae e a jiboia, de Ernesto Neto.

"Histórias Mestiças", 2014

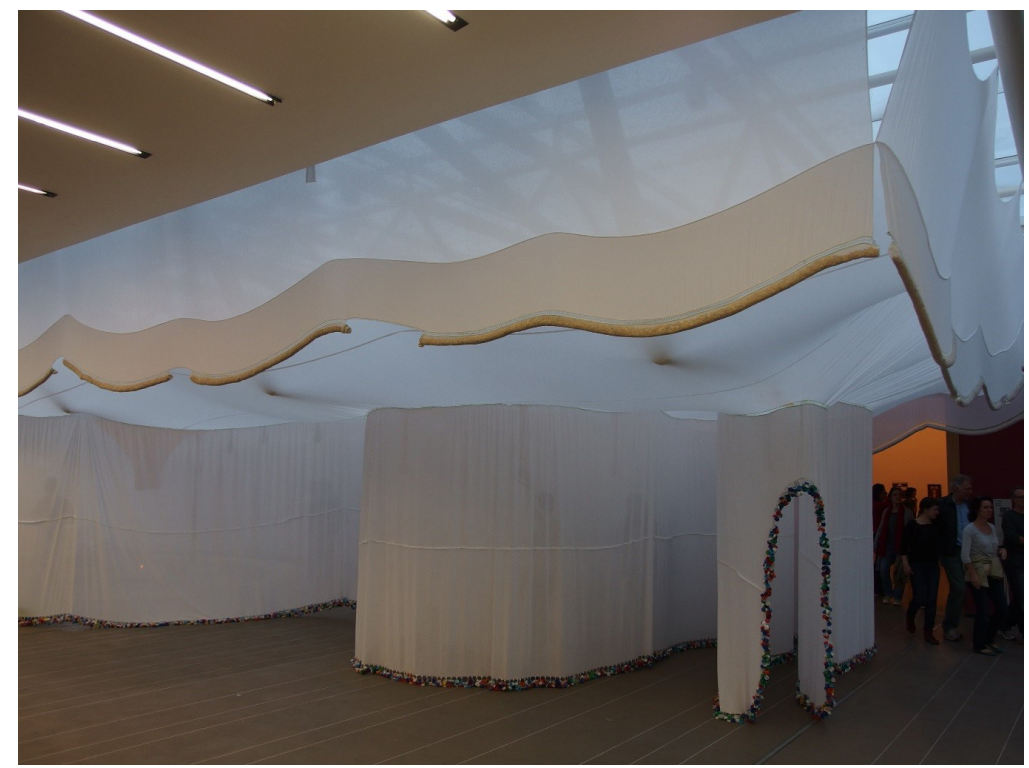

Foto: Christian Strube

Figura 4. "Em busca do sagrado...", de Ernesto Neto.

"Histórias Mestiças", 2014

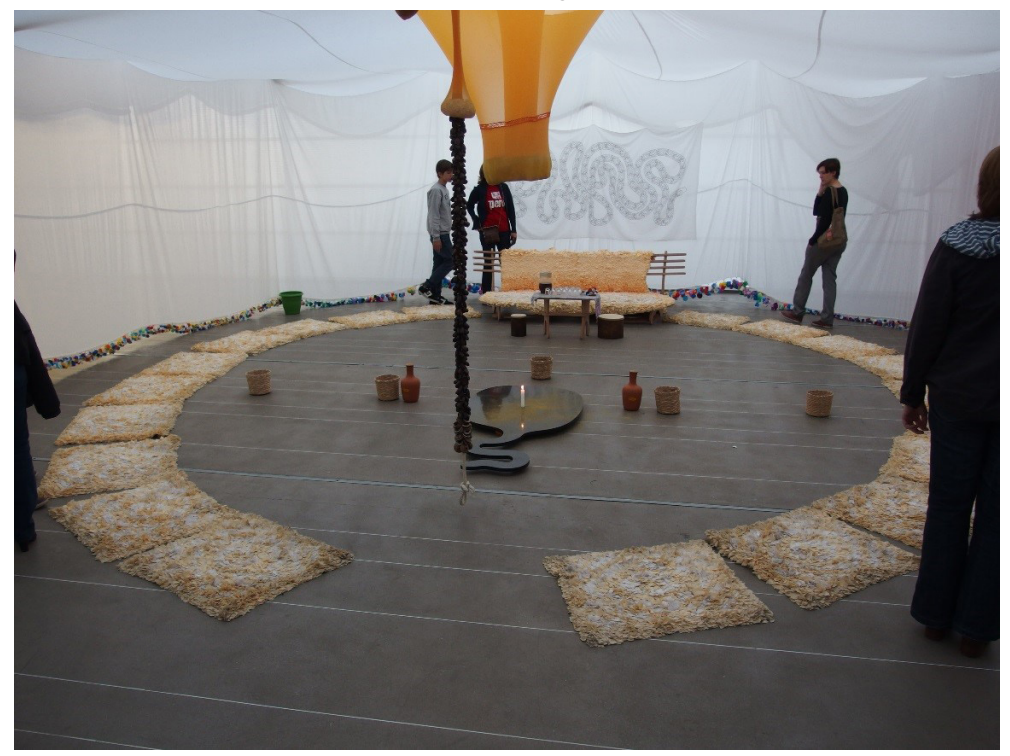

Foto: Christian Strube 
Figura 5. Detalhe da instalação da figura anterior

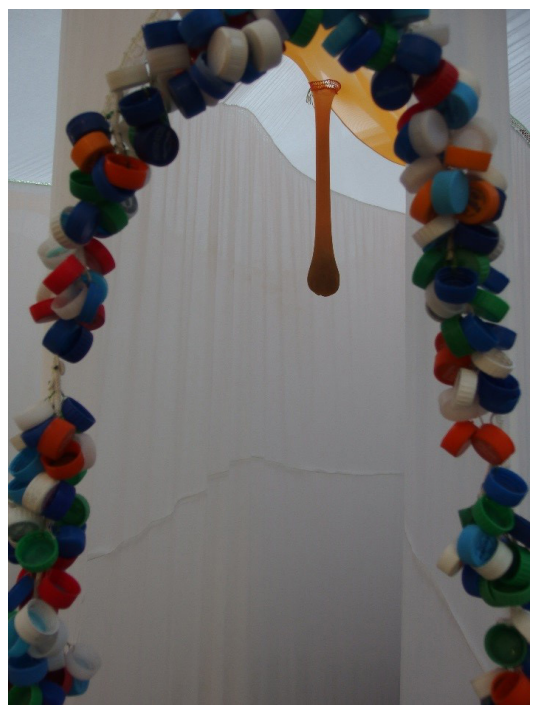

Foto: Christian Strube

Em debate promovido pelo Instituto Tomie Otahke, o artista contou que vinha lendo Eduardo Viveiros de Castro para entender o pensamento ameríndio; que dessa forma descobriu que o cosmos é superpovoado de seres não visíveis a olhos nus; que a religiosidade cristã lhe parece opressora, por ter a cruz como símbolo, ícone de sofrimento. Neto contou ter percebido que não era "ocidental" na França, quando lhe perguntaram como ele se sentia expondo no Ocidente (ou seja, em Paris). Por fim, reiterou que seu "interesse é trazer os índios para a cena e deixá-los falar. Todo mundo tem um índio dentro de si e não conhece".

O fato é que a proposta de Ernesto Neto em "Histórias Mestiças" apagou as fronteiras entre performance artística e ritual religioso. Ele construiu um templo espiritual dentro de um templo da arte. ${ }^{10}$ No geral, a repercussão foi positiva. Com exceção de uma matéria da Folha de São Paulo, na qual a repórter usou aspas para se referir ao "ritual terapêutico" com ayahuasca que presenciou no Tomie Otahke e, em seguida, descreveu com ironia as atitudes dos participantes à sua volta (Baloussier 2014: s.p.). 
Viena sediou a terceira colaboração artística entre Ernesto Neto e os Huni Kuin, na Thyssen-Bornemisza Art Contemporary - TBA 21. Na exposição "Aru Kuxipa | Sagrado Segredo", em 2015, foi construída uma casa de encontros huni kuin. O teto, ao invés de ser de palha, recebeu uma estrutura de crochê tecida por Neto, com seus pingentes característicos. As paredes foram decoradas por ele com grafismos similares ao kene (Figura 6). Havia dois bancos com formato de jiboia. Naquele espaço, intitulado KupiForesUniXawa, índios conduziram práticas medicinais, incluindo inalação de rapé, aplicação de unguentos, ingestão de plantas, cantos e defumações. A exposição vienense contava ainda com uma escultura sinuosa remetendo à serpente, um desenho com as letras A - de Adão - e E - de Eva e um espaço com uma provocação, em que livros de antropólogos e filósofos consagrados, como Derrida e Lévi-Strauss, apareciam ao lado do Livro da Cura editado pelos Huni Kuin. A lojinha do museu, durante o evento, vendeu objetos produzidos por eles.

Figura 6. Instalação de Neto em Viena, 2015

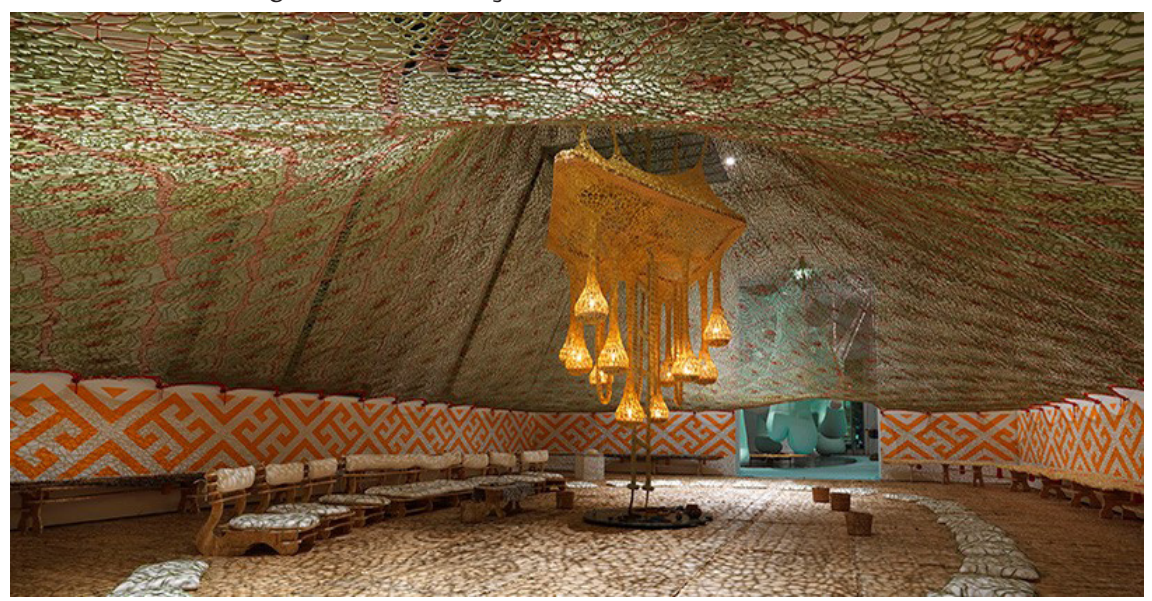

Foto da TBA 21

(http://press.tba21.org/News_Detail.aspx?id=45023\&menueid=9361) 
Figura 7. Ernesto Neto e os Huni Kuin em Viena, 2015

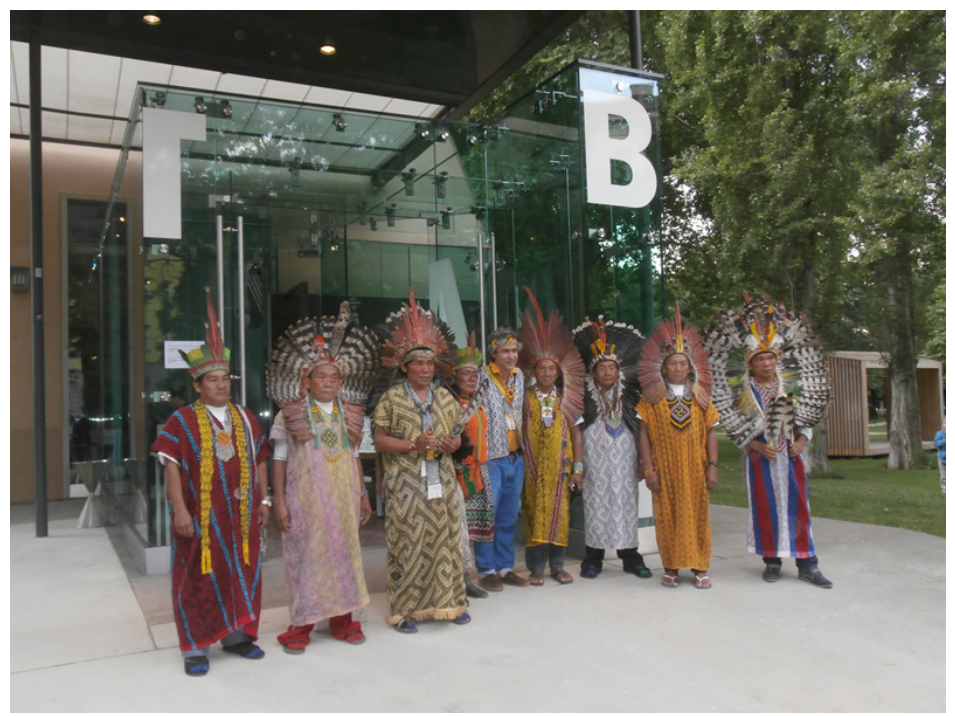

Foto: Beatriz Caiuby Labate

Paralelamente à mostra, foi organizado em Viena um seminário sobre cura, etnobotânica e práticas medicinais tradicionais. Uma das autoras acompanhou todas as atividades do grupo, que incluíram uma visita à vice-prefeita da cidade, com a presença do embaixador do Brasil, bem como cantos, danças e "limpezas" abertas ao público, que teve oportunidade de conversar com os pajés e comprar artesanato.

Acompanhando Ernesto Neto, estava uma comitiva de oito pajés. Os organizadores da mostra contaram ter viajado ao Rio Jordão, ao lado de Neto, e visitado diversas aldeias. Relataram ter enfrentado problemas com a Funai, além da resistência de outros atores locais, em sua viagem - evidência, segundo eles, da tentativa de "mediar ou bloquear suas relações com os indígenas".

Estavam presentes em Viena os já mencionados "Guardiões huni kuin", jovens profissionais liberais ou universitários cariocas entusiasmados com o uso da ayahuasca (Coutinho 2015), além dos dois organizadores do Livro de Cura, palestrantes, o staff, a curadora da mostra e a fundadora da TBA. Os Guardiões acompanhavam os pajés, ajudavam nas vendas e faziam traduções. Os pajés eram tratados com bastante reverência. A grande maioria já havia tomado junto a ayahuasca e parecia ter laços de amizade, conhecendo-se do Rio de Janeiro ou do Acre. 
Figura 8. Abertura da exposição em Viena, 2016

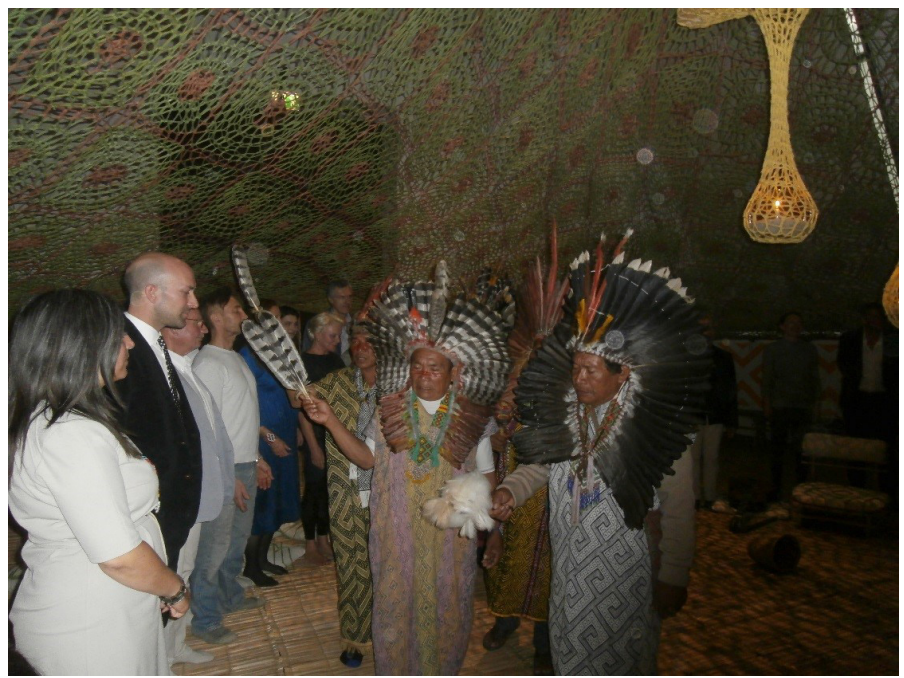

Foto: Beatriz Caiuby Labate

Figura 9. Fabiano Yawa Bane escutando tradução simultânea em Viena, 2015

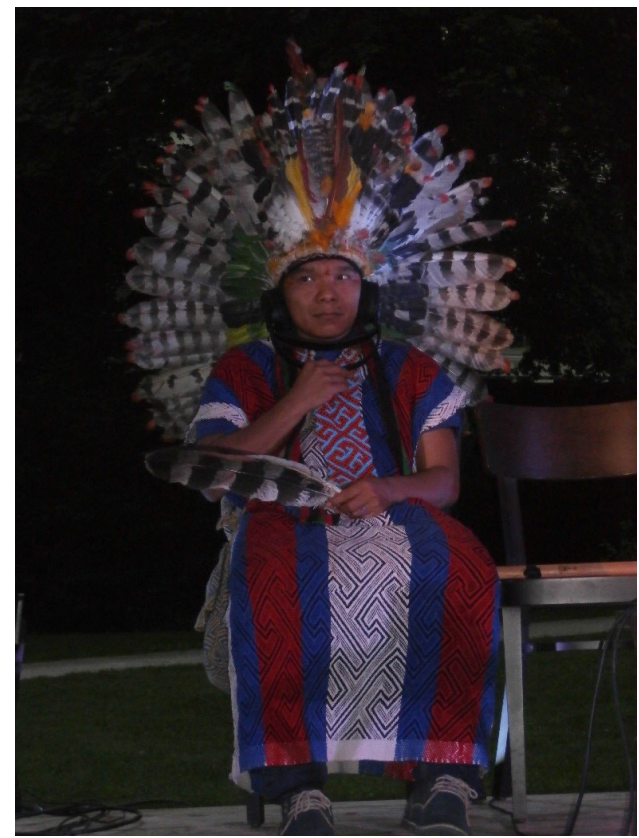

Foto: Beatriz Caiuby Labate 
Uma equipe de Veneza foi levada para cozinhar, oferecendo um sofisticado cardápio que incluiu uma mandala viva de comidas representando a Amazônia. Os Guardiões, os índios e o artista ficaram hospedados na própria TBA, que se tornou um espaço peculiar, com pessoas vestidas com roupas indígenas, pintadas, usando rapé, trajando havaianas e socializando. O ambiente era alegre, uma espécie de acampamento amazônico em pleno verão vienense. A galeria ficava dentro de um belo parque, e os passeios eram constantes. Os indígenas pareciam à vontade. Antropólogos, críticos de arte, funcionários de museus, estudiosos e curiosos gravitavam à espera das atividades oficiais, ou em conversas informais, aderindo às pinturas faciais e ao rapé. As noites eram acompanhadas por pajelanças, das quais a autora não participou.

\section{Tensões e Controvérsias}

São múltiplas as questões e as tensões suscitadas por um cenário tão complexo. Por um lado, a apropriação de métodos e temas antropológicos por sujeitos do mundo da arte, bem como a incorporação de práticas e valores de outros povos ou camadas sociais em uma exposição ampliam conhecimentos sobre os diversos Outros que ocupam posições periféricas na própria sociedade do artista ou que pertencem a sociedades distantes. Algumas vezes, esses procedimentos, caros à "virada etnográfica da arte contemporânea", levam ao questionamento do próprio sistema euro-americano das artes, colocando em xeque seus mecanismos de exclusão e suas arbitrariedades. É emblemático, nesse sentido, o depoimento dado por Neto ao site da feira ArteRio:

A academia brasileira e o Brasil têm a infelicidade de achar que a única coisa boa e importante vem da Europa e não perceberam ainda que o mundo é muito maior. [...] A gente tem que esquecer essa história que a gente é ocidental, a gente não é ocidental, a gente é brasileiro, é uma mistura de ocidental, de africano, de índio. A gente tem que estudar realmente os índios e os africanos. Enquanto a gente não estudar isso, a gente está perdendo tempo [...]. ${ }^{11}$

Por outro lado, Hall Foster (1994) aponta perigos em tais empreitadas da arte contemporânea: 1. resvalar em um neoprimitivismo ingênuo, em busca de uma autenticidade imaginada; 2 . reificar identidades; 3 . interessar-se mais pelo autoestranhamento do que pelo conhecimento do Outro. De fato, isso pode ocorrer em parcerias como as discutidas no presente texto. Embora os eventos e os discursos artísticos tenham o mérito de atingir público e mídia 
mais abrangentes do que os textos acadêmicos, e de forma mais poética e sedutora, nem sempre eles têm um embasamento empírico sólido por trás de suas enunciações. Até porque este não é seu propósito. No caso da representação de povos indígenas, existe o risco de estereotipá-los, de idealizar seu modo de vida, projetando neles suas próprias frustrações e fantasias.

Nos bastidores e nas apresentações oficiais de Viena, não foram raros os depoimentos ressaltando "a magia, a pureza e a ternura" dos índios; como os Huni Kuin "vivem harmonicamente na floresta, uma vida saudável"; apontando a "inexistência de separação entre os Huni Kuin e a floresta". Em alguns momentos, a especificidade huni kuin parecia se perder, e vinham à tona percepções de senso-comum, como aquela de os índios representarem a infância da humanidade, ou oferecerem uma espécie de redenção para o planeta e a civilização contemporânea.

Talvez estejamos diante de uma nova versão do primitivismo. Na sua primeira vertente, artistas europeus realizaram empréstimos formais de objetos "primitivos". Numa segunda vertente, que floresceu depois nos Estados Unidos, o artista estava interessado em se deixar inspirar por outras concepções (Severi 1992). O pintor nova-iorquino Barnet Neuman, na década de 1940, afirmava que, para os Kwakwiutl, um objeto pode ser algo vivo, um veículo de pensamentos abstratos complexos, um suporte para a projeção de sentimentos. Esta se tornou a fonte de inspiração para sua pintura abstrata (O'Neil 1992). Já Joseph Beuys, em 1974, realizou sua primeira performance-ritual, coabitando com um coiote recém-capturado dentro de uma galeria em Nova York. De acordo com Severi (1992:44), neste caso, "a arte é a revelação de uma primitividade utópica, desejada, experimentada". Ernesto Neto, involuntariamente, remete a ambas as vertentes do primitivismo artístico. A primeira, mais calcada na forma, ao criar instalações com formato de serpente, ou ao incorporar grafismos kene na instalação de Viena; a segunda, ao revelar seu fascínio pelos conhecimentos da floresta e pela espiritualidade indígena.

Apesar de qualquer estética primitivista postular a universalidade da arte, ela costuma renunciar ao ponto de vista antropológico sobre as obras e seus contextos (Severi 1992). O desinteresse pela Antropologia - e o desconhecimento do que fazem os antropólogos hoje - é justamente a segunda tensão que pudemos identificar. Ele vem à tona, por exemplo, em um depoimento que a curadora austríaca Zyman deu à Folha de São Paulo: “Estamos [nós, brancos, e os índios] nos experimentando mutuamente: [...] Se fizéssemos tudo sem eles, 'em nome deles', cairíamos na armadilha da antropologia. A ideia era cortar a mediação, fazê-los falar por si mesmos" (apud Neves 2015: s.p.). Durante a semana em que esteve em Viena, uma das 
autoras notou, em sete ocasiões, críticas à Antropologia feitas por diferentes sujeitos envolvidos com a exibição, sempre reiterando que aquelas iniciativas "não passavam pela intermediação da Antropologia", como se antropólogos falassem em nome dos índios e a exposição ou o livro não envolvesse mediações externas. Ironicamente, durante o período do seminário vienense, os índios falaram muito menos do que os demais presentes, que "explicavam" a vida na floresta, a simbologia dos ritos, sua experiência com a ayahuasca.

Em terceiro lugar, existem questões legais espinhosas, como o fato de, em solo brasileiro, o consumo da ayahuasca só ser permitido em contextos religiosos e, em outros países, ser totalmente proibido. A cerimônia realizada na exposição de São Paulo se situa em uma espécie de limbo legal. Uma reportagem superficial e exotizante da Folha de São Paulo sobre os rituais que ocorreram dentro da instalação de Ernesto Neto em "Histórias Mestiças" acabou gerando péssima repercussão junto ao movimento de legitimação do uso da ayahuasca no Brasil. No mesmo sentido, o anúncio aberto das sessões na Espanha colocou em risco o delicado equilíbrio com as autoridades locais, uma vez que o uso da ayahuasca não é oficialmente permitido neste país. Em Viena, o anúncio público do desejo de realizar uma sessão pareceu seguir a mesma lógica de que a expansão do consumo da ayahuasca é necessária, e o direito de consumi-la deve ser obtido a qualquer custo.

Ainda dentro da dimensão jurídica, um quarto desafio é garantir a proteção dos conhecimentos e das formas expressivas indígenas. A partir do momento em que os cantos do cipó, as técnicas de fabricação da bebida, as práticas de cura, os grafismos kene e os mitos passam a circular em museus, catálogos, na imprensa e em rituais urbanos, eles podem, em princípio, fugir do controle de seus detentores tradicionais. Publicar e publicizar a "cultura" asseguram a continuidade e a valorização de determinadas práticas e saberes. Porém, pode também ocorrer a sua utilização indevida: existe um risco potencial de que o não indígena, com ou sem consciência do fato, se aproprie do que aprendeu sem pedir autorização nem pagar por isso. E, nesse âmbito, não existem leis que protejam os índios.

Vale lembrar que, preocupada com a utilização de seu repertório gráfico por terceiros, a Federação do Povo Huni Kuin do Acre procurou o Instituto do Patrimônio Histórico e Artístico Nacional (Iphan) em 2006 e em 2007 pedindo a patrimonialização dos desenhos kene. O Iphan vem realizando consultas às aldeias desde 2011, mas até agora o registro não se concretizou. O maior empecilho está nas controvérsias entre os próprios Huni Kuin acerca dos ganhos efetivos de uma salvaguarda estatal. Afinal, a mera patrimonialização pelo Iphan não evita que surjam falsificações ou reproduções não autorizadas dos desenhos (Lima et al. 2014:227). Isto porque a legislação referente à 
propriedade intelectual pauta-se na ideia do autor enquanto indivíduo. No caso dos saberes e das expressões indígenas, trata-se de patrimônio coletivo, inclusive, muitos povos consideram que parte de seu conhecimento foi apropriada de terceiros (inimigos, outros povos, sobrenaturais). Outro problema é a distinção existente na lei entre descoberta (não protegida) e invenção (protegida). O acordo internacional TRIPs - Trade Related-Aspects of Intellectual Property Rights diz que "uma patente pode ser obtida para toda invenção, de produto ou procedimento, em todas as áreas tecnológicas, contanto que seja nova, que implique atividade inventiva e seja susceptível de aplicação industrial" (Barbosa, C., Barbosa, J. \& Figueiredo 2010: s.p.). Privilegiam-se, assim, cientistas e indústrias, em detrimento de detentores de conhecimento empírico imemorial.

No caso de parcerias artísticas entre indígenas e não indígenas, as questões se complexificam. Não nos referimos aqui especificamente à colaboração entre Ernesto Neto e os Huni Kuin, mas a iniciativas dessa natureza, de um modo geral: quem deve levar os créditos pela obra de arte? O artista já reconhecido pelas instâncias artísticas de legitimação, que normalmente é o convidado dos curadores e o responsável por conseguir espaço em museus e galerias? Apenas os indígenas com os quais o artista compartilhou experiências diretamente? Toda a etnia à qual pertencem esses indivíduos, já que se trata de conhecimentos e formas expressivas coletivos? Quem deve falar sobre o trabalho realizado em parceria? Quais os riscos de se divulgarem, por meio de uma exposição, informações normalmente restritas aos grupos indígenas em questão?

O ideal é que, ao menos, a exploração comercial ou simbólica do patrimônio cultural ocorra com participação direta de seus detentores. Na cidade australiana de Cairns, por exemplo, funciona um parque temático aborígene chamado Tjapukai, cujo proprietário não é indígena, mas cujos bilheteiros, dançarinos, arremessadores de bumerangue, instrutores de pintura facial e vendedores da lojinha são da etnia Tjapukai. Também na Austrália, os parques nacionais Kakadu, com pinturas rupestres de 40 mil anos atrás, e Uluru, com sua pedra gigante de nove quilômetros, são operados por guias aborígenes que narram as histórias de cada marca na paisagem (Goldstein 2012). Até que ponto se trata, nesses casos ou nas recentes parcerias dos Huni Kuin com não indígenas, de encenações "inautênticas", de comoditização cultural?

Esta é a quinta tensão que se coloca: a reificação de identidades e práticas culturais indígenas, potencializada em processos como a expansão da ayahuasca nos centros urbanos e a inserção de obras e artistas indígenas no sistema internacional das artes. Na exposição de Viena, ainda que parecesse 
haver real intenção dos organizadores e dos artistas em repartir benefícios econômicos com os indígenas, a questão da comodificação e da fetichização cultural não deixou de se colocar. A estética dos Guardiões e demais participantes, altamente "indianizada" (com pulseiras, colares, bolsas, pinturas faciais e corporais, e até tatuagens), a circulação constante de rapé, a realização de um ritual de cura no palco do seminário, o interesse dominante nos bastidores pela ayahuasca e a "corte" permanente aos indígenas (que, por sua vez, posavam para fotos com impressionantes cocares e trajes característicos) revelavam, a uma só vez, o interesse pelas práticas indígenas, um mercado incipiente de consumo, e uma estetização estilizada das mesmas. ${ }^{12}$

Por fim, a questão da autoria é interessante. Em Bilbao, uma das instalações se chamava "O Corpo que me carrega", e era assinada só por Neto, sem os Huni Kuin. Em São Paulo, mais uma vez, a instalação "Em busca do sagrado" era assinada por Neto. Em Viena, ao contrário, a exposição como um todo era intitulada "Ernesto Neto e os Huni Kuin". Percebemos, portanto, uma mudança na natureza da colaboração e na maneira de creditá-la, ainda que os Huni Kuin fossem designados como um todo coletivo, sem identificar individualmente os envolvidos.

\section{Potencialidades}

Em nossa breve imersão etnográfica, os Huni Kuin em contato com o artista carioca se revelaram muito interessados na parceria. Outros sujeitos que conhecem o projeto se mostraram entusiasmados com as perspectivas que abre. Escutamos afirmações (tanto dos Huni Kuin como dos Guardiões da Floresta e de alguns envolvidos no Livro da Cura) de que Neto está genuinamente interessado no universo huni kuin; que a amizade entre eles é verdadeira; que este encontro permite dar visibilidade à beleza das tradições huni kuin e chamar a atenção para a questão dos direitos indígenas. A observação de campo e as conversas com pessoas que têm acompanhado a iniciativa trazem à tona a convicção de que há algo importante e talvez inédito acontecendo, que diverge das tão conhecidas abordagens paternalistas ou opressoras dos povos indígenas.

O estabelecimento proativo de alianças com artistas, ONGs, ativistas e o movimento new age pode ser interpretado como uma estratégia dos povos indígenas de sobrevivência em um contexto nacional de marginalização, como um modo de transformação do xamanismo ayahuasqueiro no mundo contemporâneo e de adaptação a ele. Em diversos contextos amazônicos, há sinais de um vigoroso processo de reinvenção cultural, em diálogo com novos Outros - já que a incorporação do Outro sempre foi cara aos povos ameríndios (Viveiros de Castro 2002). Neste cenário, o xamanismo ocupa papel central (Labate \& Cavnar 2014; Labate \& Coutinho 2014). 
Historicamente, os Huni Kuin se reconstruíram como indígenas, sujeitos de direitos, com renovada "autoestima cultural", desde a década de 1970; a aliança com Ernesto Neto pode ser vista como uma continuidade desse processo. A identidade Huni Kuin - como, aliás, qualquer identidade cultural - é dinâmica e está em permanente construção. ${ }^{13}$ Com efeito, a sensação etnográfica advinda destes eventos é a de um ambiente vibrante e cativante, em que os Huni Kuin aproveitam a oportunidade das viagens e dos contatos para repensar e positivar sua identidade.

Faz todo sentido seu desejo de registrar uma parcela de suas tradições em suportes duráveis como livros e vídeos, de se reafirmar enquanto grupo e de ocupar um lugar político em face da sociedade nacional e de outros povos indígenas, por meio da oferta de vivências "culturais" com a ayahuasca e da participação em grandes exposições de arte. Ao mesmo tempo, é inevitável que nesses encontros práticas sejam estilizadas, filtradas e reinventadas.

Neto e sua equipe se propõem a buscar formas de diálogo justas e inclusivas. Trata-se de um projeto ousado, com poucos precedentes no Brasil e no mundo, e que talvez ainda passe por adaptações e ajustes. ${ }^{14}$ Há uma série de envolvidos, cada um com uma visão diferente; entre os próprios Huni Kuin existem divisões: alguns se opõem ao trabalho de Neto e ao Livro de Cura, outros apreciam profundamente tais iniciativas; há ainda aqueles que simplesmente observam, resignados, pois "não tem muita gente que liga para índio, então gostamos de quem tenta fazer algo por nós". Tampouco podemos esquecer as diferenças de perspectivas dos curadores, organizadores, do público, da mídia e dos participantes das sessões de ayahuasca. Mesmo os termos desta pareceria estão em movimento constante.

As colaborações, as publicações e as exposições envolvendo índios e não índios, brasileiros e estrangeiros, antropólogos, membros do movimento Nova Era e sujeitos do universo artístico representam oportunidades de troca e aprendizagem, além de darem visibilidade à sabedoria, às tradições e à criatividade indígenas. Representam também maneiras de as identidades e as práticas indígenas se transformarem e se reatualizarem.

A interpenetração entre arte, ritual e espiritualidade expressa em trabalhos como os de Ernesto Neto é fascinante. Os rituais com ayahuasca realizados neste âmbito nos convidam também a repensar a divisão estanque e reducionista entre "usos recreativos" (lúdicos, estéticos, prazerosos) e "usos sagrados" (tradicionais, ritualísticos, religiosos) dos psicoativos, bem como os limites das atuais políticas de drogas. Por outro lado, a obra de Neto, seguindo uma tendência atual, põe em xeque as fronteiras entre arte contemporânea e prática antropológica: estas parecem estar se tornando cada vez mais tênues. 
O presente texto, de certa forma, tem um caráter programático, na medida em que apresenta um esforço etnográfico inicial acompanhado pela tentativa de fazer convergirem e dialogarem campos e autores de tradições distintas dentro da disciplina. Esperamos que este artigo contribua para o surgimento de novas pesquisas nesta direção. ${ }^{15}$

Recebido em 04 de julho de 2016

Aprovado em 02 de agosto de 2017

Ilana Goldstein é Professora do Departamento de História da Arte e membro do Programa de Pós-Graduação em História da Arte da Universidade Federal de São Paulo (Unifesp), São Paulo/SP, Brasil. E-mail: <ilagolds@yahoo.com>

Beatriz Caiuby Labate é Professora Visitante do Centro de Pesquisa e Estudos de Pós Graduação em Antropologia Social (CIESAS), em Guadalajara, México, e Professora Visitante do Programa de Psicologia Leste-Oeste do Instituto de Estudos Integrais (CIIS), em São Francisco, Califórnia, Estados Unidos da América. E-mail: <blabate@bialabate.net>

\section{Notas}

1 Até alguns anos atrás, na antropologia e nos órgãos públicos, o termo mais utilizado para se referir a esse povo era Kaxinawa. Uma outra (auto)designação vem sendo empregada recentemente, por iniciativa dos próprios índios: Huni Kuin, que significa "gente verdadeira". Contudo, vários povos conhecidos como nawasubgrupo dentro da família Pano - se consideram como Huni Kuin, razão pela qual alguns antropólogos optam por manter o etnônimo Kaxinawa (Lagrou 2004). Embora estejamos cientes dessa complexidade, ao longo do presente texto utilizaremos a autodesignação Huni Kuin.

2 Uma das autoras tem pensado e escrito sobre produção artística, museus e políticas culturais (Goldstein 2008; 2012; 2013a; 2014; 2016; Fialho, Goldstein \& Proença 2016), ao passo que a outra vem refletindo, em publicações e eventos internacionais, sobre os sentidos, a circulação e as reinvenções do uso da ayahuasca (Labate 2004; Labate \& Araújo 2004; Labate \& Coutinho 2014; Labate \& Cavnar 2014; Labate \& Bouso 2013). 
3 "O yuxibu é um ser não localizável que passa pela aldeia sem destino conhecido, nem origem identificável. A volatilidade de seus laços sociais e a aleatoriedade de seus deslocamentos significam uma correlata volatilidade das formas potencialmente assumidas por esse ser" (Lagrou 2007: 24).

4 Não seria possível incluir aqui uma revisão das várias iniciativas de antropólogos e ONGs voltadas à valorização de conhecimentos e práticas culturais indígenas, em geral, e Huni Kuin, em particular. Mas gostaríamos de destacar ao menos o trabalho da Comissão Pró-Índio (CPI) do Acre, criada em 1979, para ajudar na gestão territorial e ambiental das terras indígenas, discutir educação intercultural e políticas públicas. Siã Kaxinawa, pai de Fabiano e Leopardo, parceiros de Ernesto Neto, foi aluno da primeira turma de formação indígena da CPI do Acre (Coutinho 2015).

5 Além dos Huni Kuin, os Katukina e outros sujeitos não indígenas tiveram papel fundamental na expansão do kambô. A disseminação de seu uso terapêutico urbano - diferente do uso tradicional contra a panema - foi concomitante à popularização da ayahuasca nas cidades (Lima 2014; Labate \& Lima 2014).

6 Marcela Coelho de Souza (2012) acompanhou um processo interessante entre os Kïsêdjê, antes conhecidos como Suyá. Em 2006, procurados pela Grendene para um contrato que previa a ornamentação de Giselle Bündchen, em uma campanha de sandálias, os Kïsêdjê tiveram muitas discussões até decidir que pintura e que cocar a top model poderia receber e que música seria tocada na filmagem. Tentaram evitar que ela usasse adornos plumários masculinos, que práticas recentemente incorporadas de outras etnias ficassem em evidência e que miçangas industrializadas fossem fotografadas - embora isso faça parte de sua vida na aldeia. Ao mesmo tempo, recuperaram uma pintura tradicional reservada a belas mulheres, há muito esquecida. Tratava-se, portanto, de rearranjar com criatividade certos elementos culturais e de negociar identidades de uma forma que fizesse sentido para os dois lados (Coelho de Souza 2012).

7 O Instituto Maracá, em fase de implantação em São Paulo, é uma das exceções nesse cenário relativamente árido: a instituição entende que as "artes e outras formas de expressão podem facilitar a aproximação e a comunicação do público com a temática indígena, contribuindo para a transmissão de informações sobre a realidade das culturas indígenas". Pretende, ainda, "trabalhar, sempre que possível, junto com representantes indígenas" (Calabi 2016:13, no prelo).

8 Um vídeo sobre a atuação desses pesquisadores-artistas foi produzido com o apoio da Fundação Cartier. Disponível em: https://www.youtube.com/ watch?v=zRlbRpoi0cQ. Acesso em 20/10/2015. Existe também um blog que divulga as atividades do Mahku: http://nixi-pae.blogspot.com.br/2015/03/sonho.html. Acesso em 25/032016.

9 Trecho retirado do site da galeria: http://www.fortesvilaca.com.br/artistas/ ernesto-neto. Acesso em 19/10/2015.

10 Conforme bem expressou Adriana Calabi (comunicação pessoal, maio de 2016), constituiu-se uma espécie de "escultura feita de ritual, quer dizer, feita de canto, da presença dos kaxinawa, do público, do sopro, da ayahuasca". 
11 Depoimento retirado do site da feira: http://www.artrio.art.br/pt-br/entrevistas/uma-conversa-com-ernesto-neto. Acesso em 26/03/2016.

12 Não estamos querendo dizer que se trate de práticas ou objetos "inautênticos", até porque não haveria como atestar sua "autenticidade" ou "pureza" em contextos tradicionais. A história da antropologia nos ensina que a reciprocidade e a troca são fundamentos da vida em sociedade. Hobsbawm e Ranger (1984), por sua vez, mostram que mesmo as tradições que parecem "puras" e antigas são inventadas e datadas. Mais fértil, portanto, é a abordagem dos objetos e das práticas em trajetórias e processos de circulação, considerando suas mudanças de significado, suas adaptações e suas transformações em cada contexto. Para tanto, a perspectiva de Igor Kopytoff e Arjun Appadurai, que cunharam expressões como "biografia das coisas" e "estado de mercadoria", nos parece ter um bom rendimento analítico (Appadurai 2008), inclusive para pensar como, em certas situações, pode ocorrer a introdução de dimensões indígenas em redes de significados e objetos ocidentais.

13 Vale ressaltar que trabalhamos aqui com uma noção de identidade plástica, contextual e política (Barth 2000; Cunha 1985; Hall 2006). Nesta perspectiva, qualquer processo de construção identitária é um embate entre, de um lado, elementos recorrentes de um repertório cultural e, de outro, valores ou práticas, que ganham sentido e se tornam estratégicos em novos contextos. Em outras palavras, não existe uma identidade étnica ou social única, nem definitiva, pois se trata de um processo dinâmico de construção de fronteiras entre os grupos.

14 Após a finalização do presente artigo, o trabalho de Ernesto Neto com os Huni Kuin conquistou novos países. Em entrevista ao site da feira ArtRio, no final de 2015, Neto revelou que iria enviar para o Museu de Arte Contemporânea de Tóquio "um túnel-serpente chamado 'Rio Jibóia'" e levar amigos Huni Kuin para fazer uma cerimônia em um museu às margens do Reno, na Alemanha. Disponível em: http:// www.fortesvilaca.com.br/artistas/ernesto-neto. Acesso em 19/10/2015. Em 2017, convidado para a Bienal de Veneza, Neto armou uma tenda de crochê e, junto com os Huni Kuin, realizou danças no espaço expositivo. Disponível em: http://www1. folha.uol.com.br/ilustrada/2017/05/1884304-mergulhada-no-escapismo-bienal-de-veneza-ignora-dramas-do-mundo-atual.shtml?cmpid=newsfolha. Acesso em 18/05/2017. A Federação do Povo Indígena Huni Kuin do Acre relatou assim o evento: "A convite do artista Ernesto Neto a Bienal de Veneza recebeu uma instalação artística composta por uma criação do artista mesclada a peças de arte confeccionadas por artistas e ainbu kenaya do povo Huni Kui. [...] A Federação esteve representada na pessoa de seu Presidente, Ninawa Huni Kui, e do Conselheiro Zezinho Yube, que é também Assessor do Governo do Estado do Acre. Alem da exposição de algumas peças de arte Huni kui apresentadas na forma de tecidos, miçangas e desenhos, os representantes também fizeram palestras ao público, falando sobre tradição, artes e as lutas dos povos indígenas no Brasil". Disponível em: https://fephac.wixsite.com/ fephac/single-post/2017/05/16/Participa\%C3\%A7\%C3\%A3o-dos-Huni-Kui-na-Bienal-de-Veneza. Acesso em 19/05/2017. 
15 Não podemos deixar de mencionar, por exemplo, uma outra parceria entre Ernesto Neto e lideranças indígenas, que veio à tona durante a redação deste artigo. Neto realizou uma viagem com Ailton Krenak pelas montanhas de Minas Gerais, na qual resolveram promover um encontro para discutir e divulgar a produção cultural indígena. O festival Moitará, realizado entre outubro e dezembro de 2015, no Memorial dos Povos Indígenas, Brasília, conseguiu reunir 28 etnias. Para a ocasião, Ernesto Neto pintou com grafismos xinguanos a fachada do Memorial, que é dirigido por Álvaro Tukano (Maciel 2015: s.p.). Poucos meses depois, em abril de 2016, foi inaugurada a mostra "Armadilhas indígenas", no mesmo espaço expositivo, com trabalhos de artistas indígenas e não indígenas, entre os quais uma instalação de Ernesto Neto.

\section{Referências bibliográficas}

ALTMAN, John. 2005. Brokering Aboriginal art. A critical perspective on marketing, institutions and the state. Melbourne: Deakin University/Melbourne Museum.

APPADURAI, Arjun. 2008. "Introdução: mercadorias e a política de valor". In: . (org.), A vida social das coisas. As mercadorias sob uma perspectiva cultural. Rio de Janeiro: Editora da Universidade Federal Fluminense Eduff. pp. 15-87.

BALOUSSIER, Anna Virgia. 2014. "Sob o domínio da ayahuasca". Folha de São Paulo, 20 de agosto de 2014. Disponível em: http://www1.folha. uol.com.br/fsp/ilustrada/181420-sob-o-dominio-da-ayahuasca.shtml. Acesso em 20/10/2015.

BARBOSA, Carla A; BARBOSA, João M. \& FIGUEIREDO, Patrick. 2010. "O território do conhecimento tradicional: controvérsias em torno da aplicação da legislação de patentes aos conhecimentos indígenas". Proa - Revista de Antropologia e Arte [on-line], 1(2), nov. 2010. Disponível em: http://www.ifch.unicamp.br/proa/ ArtigosII/carla_joao_ patrick.html. Acesso em 26/10/2015.
BARCELOS NETO, Aristóteles. 2001. "O universo visual dos xamãs wauja (Alto Xingu)". Journal de la Société des Américanistes, 87:137-160. . 2004. "Processo criativo e apreciação estética no grafismo wauja". Cadernos de Campo, 12:87-108.

BARTH, Fredrik. 2000. "Os grupos étnicos e suas fronteiras". In: Fredrick Barth \& Tomke Lask (orgs.). O guru, o iniciador e outras variações antropológicas. Rio de janeiro: Contra Capa Livraria. pp. 25-67.

BELTING, Hans. 2006. O fim da história da arte: uma revisão dez anos depois. São Paulo: Cosac \& Naify.

BERLO, Janet. 1999. "Identities in Inuit graphic arts". In: Ruth Phillips \& Christopher Steiner (eds.), Unpacking culture. Art and commodity in colonial and post-colonial worlds. Berkeley e Los Angeles: University of California Press. pp. 178-193.

CALABI, Adriana. 2016. Plano institucional do Instituto Maracá. São Paulo. No prelo.

CAMARGO, Eliane \& VILLAR, Diego (org.). 2013. Huni Kuin Hiwepaunibuki: a história dos Caxinauás por eles mesmos. São Paulo: Edições Sesc. 
CLIFFORD, James. 1998. "On Collecting Art and Culture". In: The predicament of culture. Twentieth century ethnography, literature and art. Massachussetts: Harvard University Press. pp. 215-251.

COLOMBRES, Adolfo. 2005. Teoría transcultural del arte. Hacia un pensamento visual independiente. Buenos Aires: Ediciones del Sol.

COSTA, Rafael Barroso Mendonça. 2009. Ayahuasca: uma experiência estética. Dissertação de Mestrado em Psicologia, Universidade Federal Fluminense.

COUTINHO, Tiago. 2011. O Nixi Pae urbano: uma possível interpretação junguiana do xamanismo amazônico. Tese de Doutorado, Programa de Pós-Graduação em Antropologia Social, Universidade Federal do Rio de Janeiro.

. 2015. "O xamanismo da floresta na cidade: um estudo de caso". Núcleo de Estudos Interdisciplinares sobre Psicoativos - NEIP. Disponível em: http://neip.info/novo/wp-content/ uploads/2015/04/coutinho_xamanismo_kaxinawa_rio_de_janeiro.pdf. Acesso em 10/12/2016

CUNHA, Manuela Carneiro. 1985. Negros estrangeiros. São Paulo: Brasiliense.

FIALHO, Ana Letícia, GOLDSTEIN, Ilana Seltzer \& PROENÇA, Renata. 2016. "Economias da arte contemporânea. Programação, financiamento e gestão em instituições culturais brasileiras". In: Gláucia Villas Bôas \& Alain Quemin (orgs.), Arte e vida social: pesquisas recentes no Brasil e na França. Marselha: OpenEdition Press, v. 1, s.p; Disponível em: http://books.openedition.org/ oep/579. Acesso em 10/12/2016
FOSTER, Hall. 1994. "The artist as ethnographer". In: J. Fisher (org.), Global visions. Towards a new internationalism in the visual arts. London: Kala Press.

GOLDSTEIN, Ilana Seltzer. 2008. "Reflexões sobre a arte 'primitiva'". Horizontes Antropológicos, v. $14 \mathrm{n}^{\mathrm{o}}$ 29: 279-314.

GOLDSTEIN, Ilana Seltzer. 2012. "Autoria, autenticidade e apropriação: reflexões a partir da pintura aborígine australiana". Revista Brasileira de Ciências Sociais, v. 27 no 79: 81-106. GOLDSTEIN, Ilana Seltzer. 2013a. "Visible art, invisible artists?". Vibrant $\mathrm{v}$. $10 \mathrm{n}^{\circ}$ 1: 474-497.

GOLDSTEIN, Ilana Seltzer. 2013b. "Artes indígenas, patrimônio cultural e mercado". PROA: Revista de Antropologia e Arte, v. $1 \mathrm{n}^{\circ}$ 5. Disponível em: http:// www.revistaproa.com.br/05/?page_ $\mathrm{id}=266$. Acesso em: 21/10/2015.

GOLDSTEIN, Ilana Seltzer. 2014. "Arte, artesanato e arte popular: fronteiras movediças". In: Adriana Oliveira \& Rose Satiko (orgs.), Bixiga em artes e ofícios. São Paulo: EDUSP. pp. 223-257.

GOLDSTEIN, Ilana Seltzer. 2016. "Pintando sonhos: a pintura aborígine da Austrália e sua inserção no sistema das artes". In: Iara Lis Franco Schiavinatto \& Eduardo Augusto Costa (orgs), Cultura visual e história. São Paulo: Alameda Editorial, v. 1. pp. 145-172.

GOULART, Sandra Lúcia. 2016. "Ayahuasca e políticas públicas culturais: estratégias de reconhecimento público das religiões ayahuasqueiras". In: Beatriz Caiuby Labate et al. (orgs.), Drogas, políticas públicas e consumidores. Campinas: Mercado de Letras; São Paulo: Núcleo de Estudos Interdisciplinares sobre Psicoativos (NEIP). pp. 117-138. 
HALL, Stuart. 2006. A identidade cultural na pós-modernidade. Rio de Janeiro: DP\&A.

HEINICH, Nathalie. 1998. Le triple jeu de l'art contemporain. Paris: Éditions de Minuit.

HOBSBAWN, Eric \& RANGER, Terence (orgs.). 1984. A invenção das tradições. Rio de Janeiro: Paz e Terra.

IBÃ, Isaias Sales. 2006. Nixi pae. O espírito da floresta. Rio Branco: CPI/ Opiac.

2007. Huni Meka. Os cantos do cipó. Rio Branco/Brasília: Iphan/CPI.

KARP, Ivan. 1991. "How museums define other cultures". American Art v. 5, n.1: 10-15.

KEIFENHEIM，Barbara. 2004. "Nixi pae como participação sensível no princípio de transformação da criação primordial entre os índios Kaxinawa no Leste do Peru". In: B. Labate \& W.S. Araújo (orgs.), O uso ritual da ayahuasca. Campinas: Mercado de Letras. pp. 97-128.

LABATE, Beatriz C. 2004. A Reinvenção do uso da ayahuasca nos centros urbanos. Campinas: Mercado de Letras.

LABATE, Beatriz C. \& ARAÚJO, W. S. (orgs.). 2004. O Uso Ritual da Ayahuasca. Campinas: Mercado de Letras.

LABATE, Beatriz C. \& BOUSO, José Carlos (orgs.). 2013. Ayahuasca y salud. Barcelona, Los Libros de La Liebre de Marzo.

LABATE, Beatriz C. \& CAVNAR, Clancy (orgs.). 2014. Ayahuasca Shamanism in the Amazon and Beyond. New York, NY: Oxford University Press.

LABATE, Beatriz C. \& COUTINHO, Tiago. 2014. "'O meu avô deu a ayahuasca para o Mestre Irineu': reflexões sobre a entrada dos índios no circuito urbano de consumo de ayahuasca no Brasil". Revista de Antropologia v. 57 $\mathrm{n}^{\circ}$ 2. São Paulo: Universidade de São Paulo: 215- 250.
LABATE, Beatriz C. \& GOLDSTEIN, Ilana Seltzer. 2008. "A preservação do intangível". Trópico - ideias de norte a sul. Disponível em: http:// www.revistatropico.com.br/tropico/ html/textos/3140,1.shl. Acesso em 12/10/2015.

LABATE, Beatriz C. \& LIMA, Edilene C.. 2014. "Medical Drug or Shamanic Power Plant: The Uses of Kambô in Brazil". Ponto Urbe 15. Disponível em: http://pontourbe.revues. org/2384. Acesso em 08/06/2017.

LAGROU, Els. 2007. A fluidez da forma: arte, alteridade e agência em uma sociedade amazônica (Kaxinawa, Acre). Rio de Janeiro: TopBooks.

. 2008. "A arte do outro no surrealismo e hoje". Horizontes Antropológicos, 29: 217-230. 2009. Arte indígena no Brasil. Agência, alteridade e relação. Rio de Janeiro: C/Arte. . 2013. "Controlar la fuidez de la forma: la sanación con el uso del 'nixi pae' ('cipó forte') entre los cashinahua". In: Beatriz Caiuby Labate \& José Carlos Bouso (orgs.), Ayahuasca y salud. Barcelona: Los Libros de La Liebre de Marzo. Pp. 120-142. . 2015. "Entre xamãs e artistas" [entrevista]. Revista Usina, jul. Disponível em: http://revistausina. com/2015/07/15/entrevista-com-els-lagrou/. Acesso em 21/09/2015. . 2004. "Identificação Huni Kuin (Kaxinawa)". Disponível em: http:// pib. socioambiental.org/pt/povo/ kaxinawa/393. Acesso em 8/11/2015.

L'ESTOILE, Benoît. 2007. Le goût des autres. De l'exposition coloniale aux arts premiers. Paris: Flammarion.

LIMA, Edilene Cofacci. 2014. "A internacionalização do kampô (via ayahuasca): difusão global e efeitos locais". In: Manuela Carneiro da Cunha \& Pedro de Niemeyer Cesarino (orgs.), Políticas culturais e povos indígenas. São Paulo: Cultura Acadêmica. pp. 91-112. 
LIMA, Joaquim Maná de et al. 2014. "Observações sobre o processo de patrimonialização dos Kene huni kuin". In: Manuela Carneiro da Cunha \& Pedro de Niemeyer Cesarino (orgs.), Políticas culturais e povos indígenas. São Paulo: Cultura Acadêmica. pp. 219-240.

MACIEL, Nahima. 2015. "Divulgação é um instrumento importante para manter viva a cultura indígena". Correio Braziliense, 22/12/2015. Disponível em: http://www.correio braziliense.com.br/app/noticia/ diversao-e-arte/2015/12/22/interna_ diversao_arte,511604/ divulgacao-e-um-instrumento-importante-para-manter-viva-a-cultura-indi.shtml. Acesso em 21/04/2016.

MITCHELL, Marybelle. 1993. "Social, economic and political transformation among Canadian Inuit from 1950-1988". In: G. Master (org.), In the shadow of the sun: perspectives on contemporary native art. Quebec: Canadian Museum of Civilization. pp. 333-356.

MORPHY, Howard. 2008. Becoming art. Exploring cross cultural categories. Sydney: University of South Austrália Press.

MURU, Agostinho Manduca Mateus Ika \& QUINET, Alexandre. 2014. Una Isi Kayawa - livro da cura do povo Huni Kut do Rio Jordão. Rio de Janeiro: Dantes.

NEVES, Lucas. 2015. "Ernesto Neto leva obra inspirada em rituais de ayahuasca a Viena". Folha de São Paulo, 29 de junho de 2015. Disponível em: http://www1.folha.uol. com.br/ilustrada/2015/06/1649044-ernesto-neto-leva-obra-inspirada-em-rituais-de-ayahuasca -a-viena. shtml. Acesso em 20/10/2015.
OLIVEIRA, Aline de. 2012. Yawa-nawa: alianças e pajés nas cidades. Dissertação de Mestrado apresentada à Universidade Federal de Santa Catarina, Florianópolis.

O'NEIL, John P. 1992. Barnett Newman. Selected writings and interviews. Berkeley e Los Angeles: University of California Press.

PERRY, Gill. 1998. "O primitivismo e o 'moderno'". In: Charles Harrison et al. (orgs.), Primitivismo, cubismo e abstração. Começo do século XX. São Paulo: Cosac \& Naify. pp. 3-85.

PADILLA, Ivan. 2010. "Qual o valor da arte?" Época Negócios, 4 de março de 2010. Disponível em: http:// epocanegocios.globo.com/Revista/ Common/0,,ERT125293-16642,00. html. Acesso em 8/11/2015.

PRICE, Sally. 2007. Paris primitive. Chicago: The University of Chicago Press.

SANTOS, Laymert Garcia dos. 2010. "Como a arte global transforma a arte étnica". In: Ana Letícia Fialho et al (org.), Depois do muro. Série Encontros vol. 2. Recife: Fundação Joaquim Nabuco/Editora Massangana. pp. 11-46.

SCHWARCZ, Lilia Katri Moritz. 2013. "A era dos museus de etnografia no Brasil: o Museu Paulista, o Museu Nacional e o Museu Paraense em finais do XIX". In: Betânia Gonçalves Figueiredo \& Diana Gonçalves Vidal (orgs.), Museus: dos gabinetes de curiosidades à museologia moderna. $2^{\mathrm{a}}$ edição. Belo Horizonte: Fino Traço. pp 119-144.

SEVERI, Carlo. 1992. "Présence du primitif. Masques et chimères dans l'oeuvre de Joseph Beuys". Cahiers du Musée National d'art moderne n. 42 : 31-47. 
. 2012. "Anthropologie de l'art abstrait. Enjeux de l'image dans la pensée de Claude Lévi-Strauss". In: Philippe Descola (org.), Claude Lévi-Strauss, un parcours dans le siècle. Paris: Odile Jacob. pp. 165-192.

SHAPIRO, Roberta \& HEINICH, Nathalie. 2013. "Quando há artificação?". Sociedade e Estado, 28(1):1428.

SOUZA, Marcela Stockler Coelho de. 2012. "A pintura esquecida e o desenho roubado: contrato, troca e criatividade entre os Ksêdjê". Revista de Antropologia, 55(1): 209-253.
VIVEIROS DE CASTRO, Eduardo. 2002. A inconstância da alma selvagem. São Paulo: Cosac \& Naify.

VELTHEM, Lucia Hussak Van. 1998. A pele de tuluperê: uma etnografia dos trançados Wayana. Belém: Museu Paraense Emílio Goeldi.

VELTHEM, Lucia Hussak Van. 2003. O belo é a fera: a estética da produção e da predação entre os Wayana. Lisboa: Museu Nacional de Etnologia/ Assírio Alvim.

WEISS, Peg. 1995. Kandinsky and old Russia: the artist as ethnographer and shaman. New Haven: Yale University Press. 
ENCONTROS ARTÍSTICOS E

AYAHUASQUEIROS: REFLEXÕES

SOBRE A COLABORAÇÃO ENTRE ERNESTO NETO E OS HUNI KUIN

\author{
ARTISTIC AND AYAHUASQUERO \\ ENCOUNTERS: REFLECTIONS ON \\ THE COLLABORATION BETWEEN \\ ERNESTO NETO AND THE HUNI KUIN
}

\section{Resumo}

Recentemente, trabalhos de Ernesto Neto ganharam destaque em museus de arte em Bilbao, São Paulo e Viena. Tiravam parte de sua força do fato de remeterem a rituais de cura com ayahuasca dos Huni Kuin (Kaxinawa). Observa-se certo paralelismo entre essa conquista de espaço para a presença indígena no sistema das artes e a chegada dos índios ao circuito urbano da ayahuasca. A circulação de novas formas de xamanismo, de consumo da ayahuasca, de objetos artísticos e performances, em redes nacionais e internacionais, atesta o vigor e a capacidade de adaptação das práticas culturais indígenas, além de representar possibilidades para diálogos transculturais. Ao mesmo tempo, esbarra em desafios espinhosos, como as proibições legais relativas ao uso da ayahuasca, a dificuldade de proteger a propriedade intelectual tradicional e a potencial reificação de identidades. $\mathrm{O}$ presente texto partirá da colaboração de Neto com os Huni Kuin para refletir sobre estas e outras questões.

Palavras-chave Ayahuasca; Arte indígena; Arte contemporânea; Huni Kuin; Ernesto Neto.

\section{Abstract}

This article addresses the installations of the Brazilian artist Ernesto Neto in collaboration with the Huni Kuin people, exhibited in Brazil, Spain and Austria. It draws a parallel between the arrival of Brazilian Indians in the urban circuit of ayahuasca and their presence in art institutions. These new forms of shamanism and ayahuasca circulate through national and international urban networks, attesting to the great vigour and adaptability of indigenous contemporary traditions. On the other hand, they raise controversial issues, linked to the respect for collective and ancient intellectual property and to stereotyped representation of "Others". Furthermore, the consumption of ayahuasca in Brazil is limited to certain settings and abroad it is often illegal. It will be argued that both the expansion of ayahuasca use and the insertion of indigenous arts in museums and galleries, point to a creative and fertile intercultural dialogue, but also raise issues about cultural "authenticity", appropriation, and commodification.

Key words: Ayahuasca; Indigenous arts; Contemporary art; Huni Kuin; Ernesto Neto. 


\section{ENCUENTROS ARTÍSTICOS Y AYAHUASQUEROS: REFLEXIONES SOBRE LA RELACIÓN ENTRE ERNESTO NETO Y LOS HUNI KUIN Resumen}

Recientemente, trabajos de Ernesto Neto adquirieron relevancia en museos de arte en Bilbao, São Paulo y Viena. Parte de su fuerza radicó en el hecho de remitir a rituales de curación con ayahuasca por los Huni Kuin (Kaxinawa). En ellos se observa cierto paralelismo entre esa conquista de espacio para la presencia indígena en el sistema de las artes y la llegada de los indios al circuito urbano de la ayahuasca. La circulación de nuevas formas de chamanismo, de consumo de la ayahuasca, de objetos artísticos y performances, en redes nacionales e internacionales, refleja el vigor y la capacidad de adaptación de las prácticas culturales indígenas, además de representar posibilidades para diálogos transculturales. $\mathrm{Al}$ mismo tiempo, se enfrenta a desafíos espinosos, como las prohibiciones legales relativas al uso de la ayahuasca, la dificultad de proteger la propiedad intelectual tradicional y la posible resignificación de identidades. El presente texto parte de la colaboración de Neto con los Huni Kuin para reflexionar sobre éstas y otras cuestiones.

Palavras clave Ayahuasca; Artes indígenas; Arte contemporáneo; Huni Kuin; Ernesto Neto. 